\title{
Dynamical Effects of Mountains on the General Circulation of the Atmosphere: III. Effects on the General Circulation of the Baroclinic Atmosphere
}

\author{
By Hajime Nakamura \\ Geophysical Institute, Tokyo University \\ (Manuscript received 1 October 1977, in revised form 19 August 1978)
}

\begin{abstract}
In order to investigate dynamical effects of mountains on the general circulation of the baroclinic atmosphere, the model developed in Part I is integrated for about 150 days. A simplified diabatic heating function and the Newtonian cooling evaluated from observational data are adopted for the thermal process in the model. The $6.5^{\circ} \mathrm{K} / \mathrm{km}$ convective adjustment is used to parametarize the vertical convective mixing of heat. The nonlinear viscosity and the vertical momentum diffusion are also included.

Time integrations are performed with and without an idealized steep mountain like the Tibetan Plateau. The model without the mountain simulates'successfully the gross features of the general circulation similar to the real atmosphere. That is, the westerly wind in the middle latitudes, the easterly wind in the tropics and the meridional three cell circulation are well simulated. Baroclinic unstable waves are well developed, though a little less active than the real ones. However, there are some defficiency in the model atmosphere. For example, the subtropical jet is too strong and its position is too south compared with the real atmosphere due to the large latitudinal gradient of the diabatic heating near $20^{\circ}$ latitude. The active region of baroclinic waves is limited to relatively higher latitudes.

Incorporating the mountain does not change these features largely. The most remarkable change is the northward shift of the subtropical high. It is located at $30^{\circ}$ latitude in the model without the mountain while it is at $45^{\circ}$ latitude in the model with the mountain. The region of the downward motion in the subtropics also expands northward. This is due to the geostrophic adjustment of the pressure field to the westerly wind weakened by the blocking effect of the mountain. This phenomenon may be one of the causes of the northward shift of the dry area in the Eurasian continent. We may also speculate that this process contributes to the formation of the Siberian high to some extent.

The mountain does not excite stationary planetary waves so much as expected frcm the observation and other studies, because of the weak westerly wind over the mountain.

In addition, a zonally symmetric circulation is obtained. Though there is a large difference between it and the real atmosphere, it is considerably similar to the real atmosphere compared with the results of Hunt (1973) who also investigated a zonally symmetric circulation. It is supposed that one of the causes of the difference between the two results is the difference of the scheme used for the nonlinear horizontal viscosity in the two models.
\end{abstract}

\section{Introduction}

For the general circulation of the atmosphere, it is an interesting problem to examine the effect of mountains on baroclinic waves. Egger (1972) and Edelmann (1974) investigated numerically the effect of mountains on a particular cyclone or anticyclone and simulated splitting of low pressure area and jumping of the low center. It may be expected that the activity of baro- clinic waves is changed by mountains and hence its contribution to the general circulation may also be varied. Therefore, it is interesting to see how the role of baroclinic waves on the general circulation of the atmosphere is influenced by mountains.

In Part II we examined dynamical effects of mountains on a westerly jet which is maintained by artificial forcing so as to be restored to a prescribed equilibrium state in which the jet has no 
vertical shear. It was revealed that steepness of the mountain has an important effect on the blocking effect and the streching and shrinking effects of vortex tube. The latter is related with the production of planetary waves. Though the experiment gave us an important information, its situation is fairly different from the real atmosphere. As is well known, baroclinicity is one of the most important factors in the real atmosphere. Due to baroclinicity the vertical shear of the wind is produced and a maximum of the westerly jet appears in the upper atmosphere. Thus the driving force of the westerly jet is quite different between the real atmosphere and the barotropically forced jet as mentioned in Part II. It will be necessary to see whether the dynamical effects shown in the case of the barotropically forced jet are also significant in the baroclinic atmosphere or not. The effects may be modified in the baroclinic atmosphere. To answer such question is another interesting problem in the present study.

Since baroclinicity is produced by heat imbalance between the equator and the pole, it is necessary to consider the latitudinal diabatic effects in the model, which is not considered in Part II. However, since it is not our main concern to study thermal effects in detail, we incorporate diabatic effects in a very simplified form as was used by Kida (1977). Net heating rate in the annual mean evaluated from observational analysis is assumed in the model as a time independent function of latitude and height. Since this net heating rate is independent of the temperature of the model atmosphere, the Newtonian cooling is also adopted to insure thermal balance of the atmosphere.

We compare the two runs with the without the mountain. This method is the same as used in the studies of Mintz (1968), Kasahara and Washington (1971) and Manabe and Terpstra (1974). The shape of the mountain is simplified in the same way as in Part II, because our interest is not to discuss the effect of the mountain in quantitative detail. A fairly steep mountain is incorporated.

As the initial condition for time integration of the general circulation models, an isothermal atmosphere at rest has been often used (e.g., Manabe et al., 1965; Kasahara and Washington, 1971) because it is regarded to give no particular hysteresis on the performance of time integration. However, since it needs very long computational time to reach a quasi-equilibrium state, the ob- served states were also adopted frequently as the initial condition to save computer time by many modellers (e.g., Gilchrist et al., 1973 and Kida, 1977). In the present work a solution of the zonally symmetric circulation is used as the initial condition. It is obtained by a two-dimensional model of latitude and height where no effects of the disturbances in the zonal direction is considered. It is of some interest to investigate the zonally symmetric circulation. Comparing the circulation with that of the real atmosphere or those obtained by more realistic numerical models, we will obtain an idea about the role of baroclinic unstable waves and planetary waves for the maintenance of the general circulation. Hunt (1973) used the GFDL general circulation model for the integration of the zonally symmetric atmosphere. We will also compare the result obtained by the present model with his result.

\section{Design of the experiments}

\subsection{Brief description the model}

The numerical model is the same developed in Parts I and II. The integral domain is a halfhemisphere and its top is placed at $100 \mathrm{mb}$. Therefore, the model does not include the stratosphere. The mean surface pressure is set to be $1,000 \mathrm{mb}$ when there is no mountain. The model atmosphere is devided into 8 layers with an equal grid size $\Delta \sigma^{k}$. The horizontal grid sizes $\Delta \lambda$ and $\Delta \varphi$ are $5^{\circ}$ respectively. The parameter $k_{2}$ in the nonlinear viscosity term is changed here to 0.07 .

\subsection{Convective adjustment}

Manabe and Strickler (1964) introduced a method of the $6.5^{\circ} \mathrm{K} / \mathrm{km}$ convective adjustment in place of treating the process of the moist convective motion explicitly. In this paper we use a modified scheme. If the lapse rate $\partial T / \partial z$ is less than the critical lapse rate $\Gamma$, there occurs the vertical mixing of heat which is expressed by

$$
\frac{\partial T}{\partial t}+\cdots=\frac{1}{\rho} \frac{\partial h}{\partial z}
$$

where

$$
h=\rho K_{T v}\left(\frac{\partial T}{\partial z}-\Gamma\right)
$$

$\rho$ is the density and $K_{T v}$ the coefficient of the vertical eddy diffusion of heat. If $\partial T / \partial z>\Gamma$, no vertical mixing of heat occurs. The critical lapse rate $\Gamma$ is assumed to be $-6.5^{\circ} \mathrm{K} / \mathrm{km}$ in this study. In practice Eqs. (1) and (2) are transformed into the corresponding forms in the $\sigma$ coordinate. Since the vertical heat exchange 
occurs rapidly in the convective motions, $K_{T v}$ is assumed to be very large. Here a value of $500 \mathrm{~m}^{2} / \mathrm{s}$ is adopted, which gives almost instantaneous mixing of heat between the two adjacent layers. Therefore, its effect is nearly the same as that of Manabe and Strickler who required that the adjustment should be realized at one time step. For this purpose they used an iterative method. Our mathod will save the computer time.

\subsection{Diabatic heating terms}

Heating effects in the time change of the temperature is assumed to be expressed by two terms, i.e., an external function of the net diabatic heating rate and the Newtonian cooling:

$$
\frac{\partial T}{\partial t}+\cdots=Q+\frac{1}{\tau_{N}}\left(T_{e}-T\right)
$$

where $Q, \tau_{N}$ and $T_{e}$ are the net diabatic heating, the time constant of the Newtonian cooling and the equilibrium temperature, respectively.

The diabatic heating $Q$ is a time independent function of latitude and height. Following Kida the latitude-height distribution of $Q$ is obtained from the net heating rate which was estimated from the observational analysis of heat budget by Newell et al. (1971). $Q$ is the sum of the radiation, the latent heat liberation and the boundary layer heating. Although Kida used the data of the southern hemisphere, we use the one of the northern hemisphere because of the relative importance of mountains in this hemisphere. The original data are available for winter and summer. The diabatic heating $Q$ shown in Fig. 1

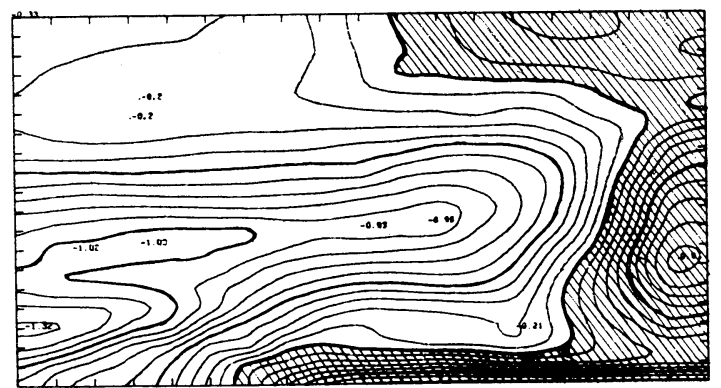
0 UIABRTIC HEATING (DEG/DAY)
$S T=0.00$
LAT-H ZONAL MEAN O YA O DAY O HR O MIN O SEC BO=0.10

Fig. 1 Latitude-height distribution of the diabatic heating function $Q$. Contour interval is $0.1^{\circ} \mathrm{K} /$ day. Shaded area shows positive heating. Leftside boundary is the pole and rightside one is the equator. Height is used as the vertical coordinate. Bottom is $0 \mathrm{~km}$ and top is $19 \mathrm{~km}$. is obtained by averaging the data of two seasons. Comparing this with that of the southern hemisphere obtained by Kida (Fig. 2 in his paper), we notice that there is a large latitudinal gradient of $Q$ near about $20^{\circ}$ latitude. As will be shown later, this drives an unrealistically strong jet over the subtropical region.

$\tau_{N}$ is set to be 20 days as same as Kida. $T_{e}$, which is a function of latitude and height, is obtained by the results of Newell et al. in the similar way as $Q$ and shown in Fig. 2.

\subsection{Mountain}

We incorporate an idealized mountain similar to the Tibetan Plateau. It has the same rectangular shape as that used in Parts I and II. Its height is $4 \mathrm{~km}$ and the size is $25^{\circ}$ in longitudinal span and $15^{\circ}$ in latitudinal span at the top and its sides are slopes with the inclination of $4 \mathrm{~km} / 5^{\circ}$. Different from the position in the former Parts, it is placed at $35^{\circ}$ latitude, that is, about the same position as the Tibetan Plateau.

\section{Zonally symmetric circulation}

As mentioned in the Introduction, a solution of the zonally symmetric circulation is used as the initial condition. In this section we compare the result of the zonally symmetric solution with the result obtained by Hunt. The zonally symmetric model used in this study (refered to as the ZS model hereafter) is the three dimensional model having longitudinal span of only 4 grid sizes. The cyclic condition is applied at the eastern and western boundaries. Although there is a possibility that small-scale eddies with the zonal wavelength less than $20^{\circ}$ become unstable, they will be suppressed by the effect of diffusion because of their very small growth rates.

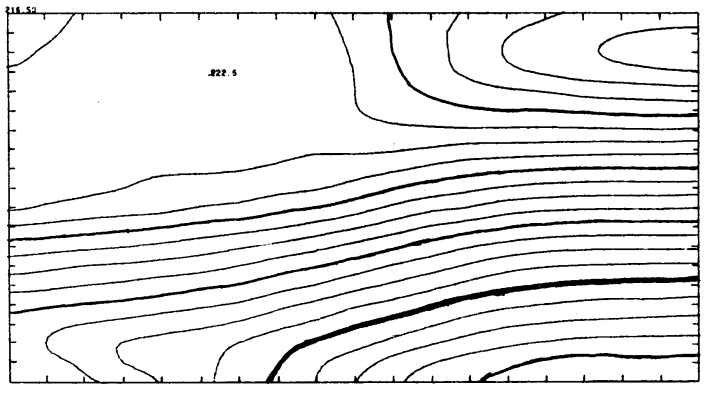

TE (OBSERVATION)

$S T=273.00$

$L-H$ ZONAL MEAN O YR O DAY O HR O MIN O SEC $B D=5.00$

Fig. 2 As same as Fig. 1 except for $T_{e}$ obtained from the observational data. Contour interval is $5^{\circ} \mathrm{K}$ and standard line is $273^{\circ} \mathrm{K}$. 
It needs about 150 days for the model atmosphere to reach an equilibrium state. Latitudeheight distribution of the temperature in the final state is shown in Fig. 3. Comparing this with the observation (Fig. 2), it is found that the temperature near the surface is higher by about $10^{\circ} \mathrm{K}$ in the equatorial region and lower by about $20^{\circ} \mathrm{K}$ in the polar region. Since the net heating rate is realistic, this temperature difference should be compensated by the northward heat transport due to the large-scale eddies and planetary-scale waves, which are not included in the ZS model. Corresponding to the low temperature near the pole, the surface pressure is higher there than in the lower latitudes (see Fig. 15). However, the pressure difference between the pole and the equator is small compared with that of Hunt's model, since the cooling near the pole is weaker in the ZS model.

There are two regions where the horizontal gradient of the temperature is large. The one is at the mid-latitudes and corresponds to the baro-

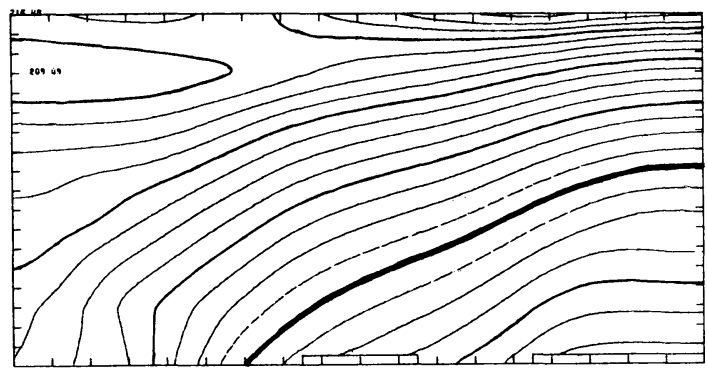

TEMPERATURE

$5 T=273.00$

LAT-H ZONAL MEAN O YR $1100 A Y$ HR O MIN O SEC BD $=5.010$

Fig. 3 Latitude-height distribution of the temperature in the ZS model. Parameters are as same as Fig. 2, but the vertical coordinate is pressure. Top is $100 \mathrm{mb}$ and bottom is $1,000 \mathrm{mb}$.

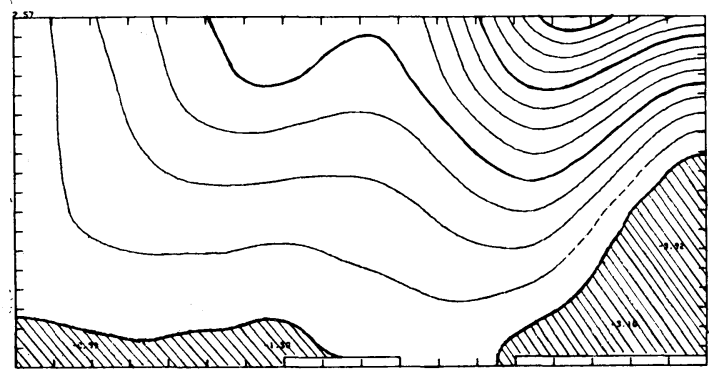

ZONAL WIND (M/SEC)

$5 r=0.00$ LAT-H ZONAL MEAN O YR $1100 A Y$ O HR O MIN O SEC BD $=5.00$

Fig. 4 As same as Fig. 3 except for the zonal velocity. Contour interval is $5 \mathrm{~m} / \mathrm{s}$. Shaded area shows the easterly wind. clinic zone in the real atmosphere. The large gradient near $20^{\circ}$ latitude has no counterpart in the real atmosphere. Even in winter a large temperature gradient is limited to the north of $30^{\circ}$. This temperature gradient may be caused by the large gradient of $Q$ near $20^{\circ}$ latitude (Fig. 1). Corresponding to the temperature gradients there are two maxima of the westerly wind (Fig. 4). The one is near $60^{\circ}$ latitude and the other is at about $20^{\circ}$ latitude. The latter may correspond to the subtropical jet. However, the jet is extraordinarily strong compared to the real one. The easterly winds appear in the equatorial region and in the lowest layer of the atmosphere north to $50^{\circ}$ latitude. In the result of Hunt, the easterly wind appeared only in the lowest layer near the pole. Moreover, strong westerly wind dominated nearly the whole atmosphere (see Fig. 2 in Hunt's paper). The pattern of the westerly wind looks to be similar to the solid rotation. The wind has

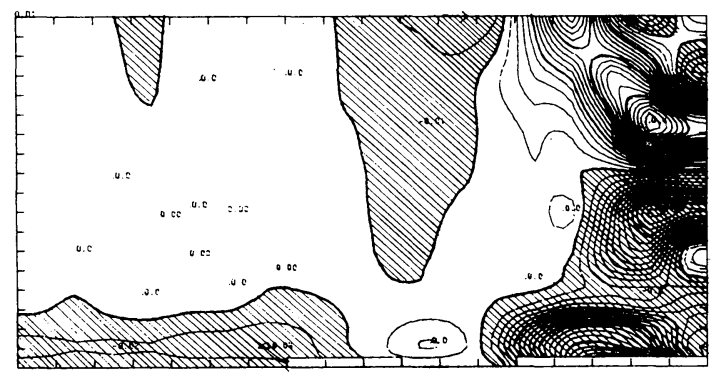

MERIDIONAL WIND (M/SEC)

$51-0.00$ LAT-H ZONAL MEAN O YR $1100 A Y O$ HR O MIN O SEC 80-0.02

(a)

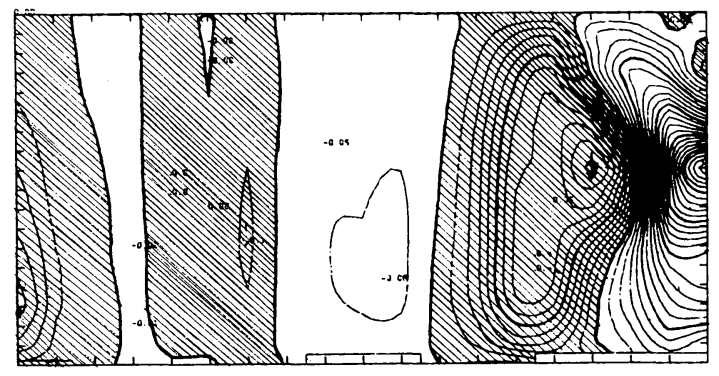

VERTICAL P-VELOCITY (1.E-4MB/SEC) ST-0.00 LAT-H ZONAL MEAN O YR $1100 A Y$ HR O MIN O SEC BD-0.05

(b)

Fig. 5 As same as Fig. 3 except for the (a) meridional velocity and (b) vertical $p$-velocity. Contour intervals are (a) $2 \mathrm{~cm} / \mathrm{s}$ and (b) $5 \times 10^{-6} \mathrm{mb} / \mathrm{s}$. Shaded area shows the (a) southward flow and (b) downward flow. 
its maximum at the equator with the magnitude of about $100 \mathrm{~m} / \mathrm{s}$ at the upper troposphere.

Fig. 5 shows the mean meridional wind and the vertical $p$-velocity. It is seen from the figure that a three-cell circulation is formed, though some irregularities exist. The intensity of the equatorial Hadley cell is of the same order as that in the real atmosphere. The direct cell in the polar region expands to the south as far as $45^{\circ}$ latitude, though weak in the southern region. There is a weak indirect cell between the two direct cells. In the real atmosphere the midlatitude indirect cell is a reflection of the heat transport by large-scale eddies. Since they are not included in the ZS model, the indirect cell is maintained by a local difference of the net heating rate and the diffusion term. In the Hunt's dry model there is a single large Hadley cell in the whole hemisphere, while there are 4 cells in his moist model. He suggested that the vertical diffusion effect is important to produce these cell patterns together with the treatment of moisture effect.

As is well known, the equatorward flow of the Hadley cell transports small angular momentum from the mid-latitudes to the low latitudes and the easterly wind appears in the equatorial region. The upward branch of the Hadley cell in turn transports the easterly momentum into the upper atmosphere. Therefore, if we consider the effect of the mean circulation only, it is inferred that near the equator the easterly wind should be dominant in the region where the mean upward motion exists. Moreover, since baroclinicity is weak near the equator, the vertical shear is also weak. In the ZS model, however, there appears the westerly wind in the upper atmosphere of the equator and in the Hunt's model there is the westerly wind at all heights. One possible origin of the equatorial westerly wind is the effect of

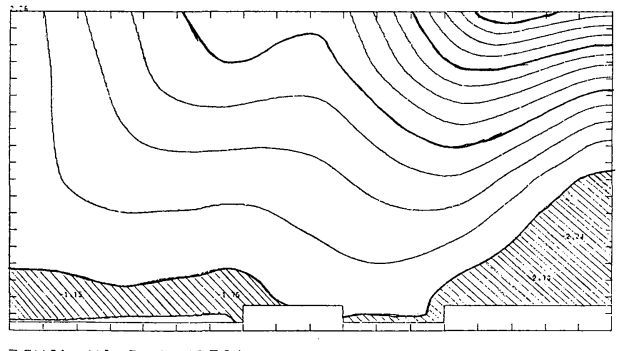

ZONAL WIND (M/SEC)

$S T=0.00$

LAT-H ZONAL MEAN O YR $230 D A Y$ O HR O MIN O SEC BD $=5.00$

Fig. 6 As same as Fig. 4 except for the use of the Smagorinsky's nonlinear viscosity with $k_{1}=0.16$. the horizontal diffusion term. The westerly momentum produced in the mid-latitudes at the upper levels is transported southward by the horizontal diffusion and changes the wind in the upper equatorial atmosphere to the westerlies. In the real atmosphere the horizontal diffusion is considered to be very small, but the nonlinear viscosity used in the model has a large effect in some situation. As described in part $I$, the scheme used in the ZS model is formulated in order to extinguish the computational noises such as the 2-grid waves. However, since it smoothes a sharp gradient of the wind velocity (more precisely, the gradient of angular velocity) so as to make the distribution of the wind approach to the solid rotation, the westerly momentum of the jet at $20^{\circ}$ latitude tends to spread to the equatorial region. In the Hunt's model the nonlinear viscosity proposed by Smagorinsky (1963) was used. As shown in Part I, this affects large-scale disturbances more strongly than that used in the ZS model. Fig. 6 shows that the westerly wind in the upper equatorial atmosphere becomes stronger and the height of the easterly wind is lowered by about $100 \mathrm{mb}$ when a Smagorinsky's type diffusion is used in the ZS model. The westerly wind in the lower equatorial atmosphere in the Hunt's model may be explained as the result of the vertical diffusion of the westerly momentum in the upper equatorial atmosphere. The vertical diffusion used by Hunt is different from that in this paper.

\section{Time integration}

To the steady state solution of the ZS model random perturbations of temperature with the amplitude of $1^{\circ} \mathrm{K}$ and the geostrophic wind adjusted to them are added. In order to make baroclinic waves develop rapidly, we add the waves obtained by a $1 / 6$ hemispheric model to the perturbations in the half hemispheric model. Time integration starts without the mountain and is continued until 69 days. Fig. 7 shows time change of the area weighted hemispheric mean of the total, zonal and eddy kinetic energies. The initial disturbances fade out in the first 20 days and after that new disturbances develop gradually. It is seen that the eddy kinetic energy reaches a quasi-equilibrium state after day 60 . From day 69 to day 70 the mountain is built up linearly with time in a day. It needs about 30 days to die out the disturbances due to sudden incorporation of the mountain. After day 110 the model atmosphere with the mountain reaches 
a quasi-equilibrium state. The integration is continued until day 185. The integration without the mountain is also continued from day 69 to day 155. Hereafter, we call the model with no mountain as the N-Mt model and that with the mountain as the $\mathrm{H}$-Mt model.

In Fig. 7 we see that the zonal kinetic energy is considerably large compared with that of the real atmosphere. Since the values are calculated as the area weighted average, the strong jet in the lower latitudes contributes much to the large zonal kinetic energy. The magnitude of the zonal kinetic energy does not differ greatly between the N-Mt model and the $\mathrm{H}$-Mt model (slightly smaller in the H-Mt model) and is almost the same as that of ZS model.

The eddy kinetic energy is small in the two models compared to that of the real atmosphere. However, it does not mean that the development of unstable baroclinic waves is poorly simulated in the two models. As will be seen later, the actively of baroclinic waves are limited to the relatively high latitudes and the disturbances are weak in the low latitudes. Therefore, the average over the whole hemisphere becomes small.

Fig. 8 shows synoptic patterns at some special days. In the N-Mt model baroclinic waves appear in the high and middle latitudes. They develop very well and show a pattern similar to those of the real atmosphere. For examples, the NESW tilt of the trough and the westward tilt of the axis with height are observed. The dominant zonal wavenumber is 4 in the high latitudes and 6 in the middle latitudes. The subtropical high belt is clearly seen along $30^{\circ}$ latitude circle and the polar region becomes a low pressure area.

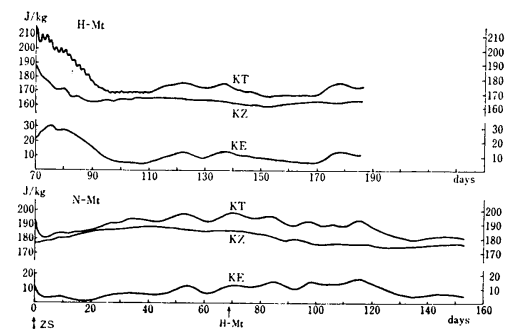

Fig. 7 Time change of the total (KT), zonal (KZ) and eddy (KE) kinetic energies. They are area-weighted averages and are devided by the mean density. Unit is $\mathrm{m}^{2} / \mathrm{s}^{2}(\mathrm{~J} / \mathrm{kg})$. Lower graph shows for the case of the N-Mt model and the upper shows for the case of the H-Mt model which started from day 70 of the N-Mt model.

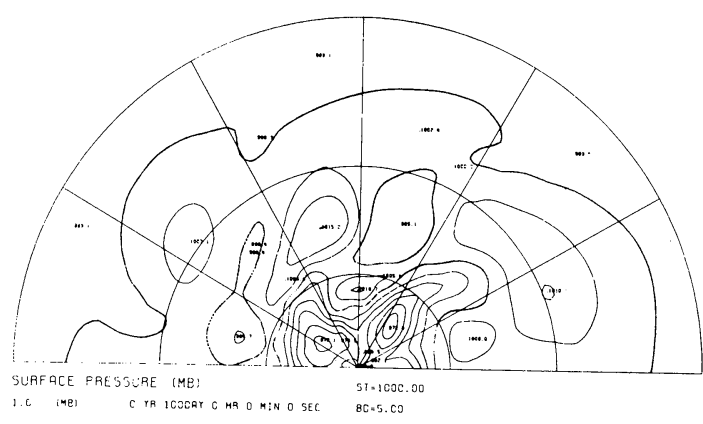

(a)

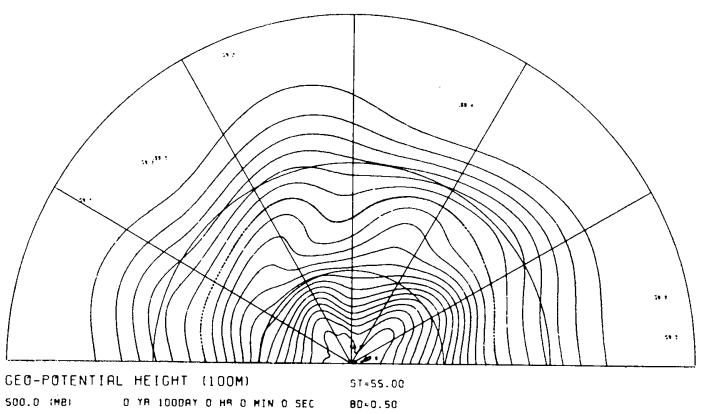

(b)

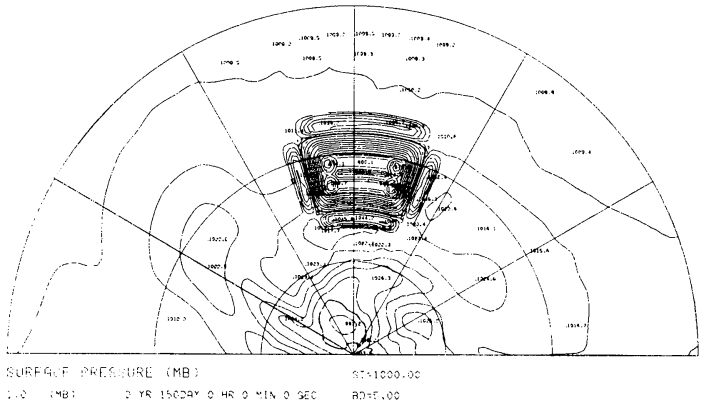

(c)

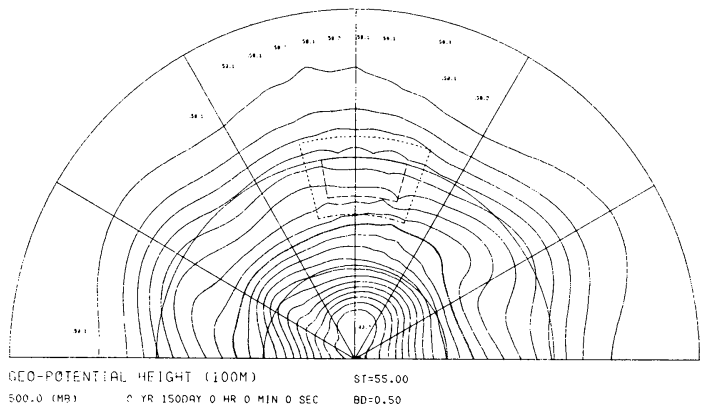

(d)

Fig. 8 Synoptic patterns at day 100 in the N-Mt model and at day 150 in the H-Mt model. (a) surface pressure and (b) geopotential height at $500 \mathrm{mb}$ in the $\mathrm{N}-\mathrm{Mt}$ model and (c) surface pressure and (d) geopotential height in the H-Mt model. 
In the $\mathrm{H}$-Mt model the subtropical high belt shifts northward to $45^{\circ}$ latitude and the region of active synoptic-scale disturbances is also shifts to higher latitudes. However, the development of baroclinic waves is sufficiently strong.

\section{Time mean state}

Time means are computed from the data taken once every day during the period of day 70 to 130 in the N-Mt model and day 120 to 180 in the $\mathrm{H}$-Mt model.

\subsection{Temperature}

Fig. 9 shows latitude-height distributions of the zonal mean temperature for the N-Mt and the H-Mt models. Comparison with that of the ZS model (Fig. 3) shows that the surface temperature is higher by about $15^{\circ} \mathrm{K}$ at the pole and lower by about $3^{\circ} \mathrm{K}$ near the equator in the $\mathrm{N}-\mathrm{Mt}$ model. The difference becomes smaller with increasing height. It is obvious that the increase of temperature in the polar region is the result of the poleward heat transport by baroclinic

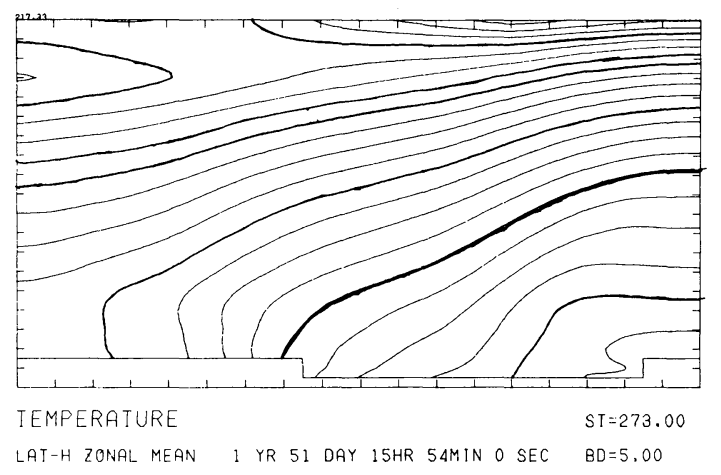

(a)

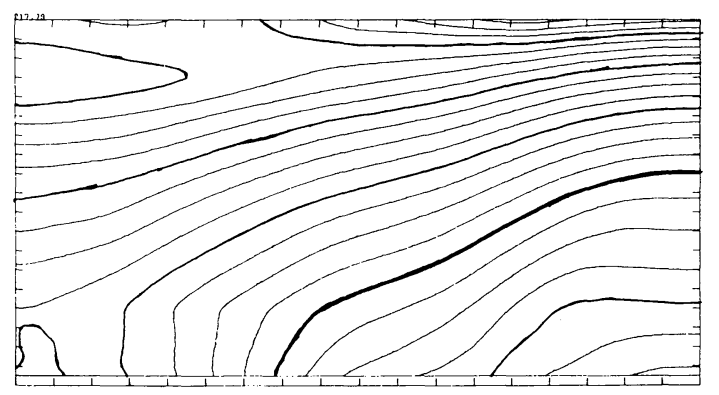

TEMPERATURE

LAT-H ZONAL MEAN

(b)

Fig. 9 As same as Fig. 3 except for the zonal mean temperature in the (a) N-Mt model and (b) H-Mt model.

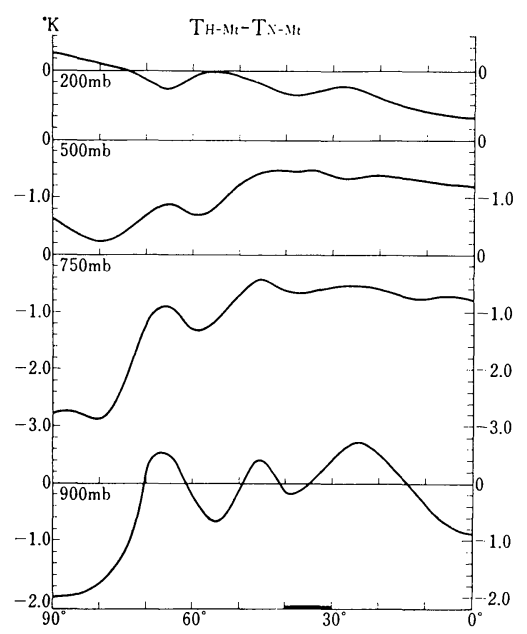

Fig. 10 Differences of the zonal mean temperature in the $\mathrm{H}-\mathrm{Mt}$ model from that in the $\mathrm{N}-\mathrm{Mt}$ model at $200,500,750$ and $900 \mathrm{mb}$ levels.

waves. However, the heat transport is still insufficient because the temperature is lower by about $5^{\circ} \mathrm{K}$ near the pole and higher at the equator than that of the observation (see Fig. 2). This discrepancy may be due to the simplicity of the model, that is, lack of the realistic boundary conditions such as land and sea contrast or other effects. The heat transport by planetary waves is not included in the N-Mt model. Development of baroclinic waves is slightly weak too.

Fig. 10 shows the temperature difference between the N-Mt model and the H-Mt model and we see that near the pole the temperature is lower by about $2^{\circ} \mathrm{K}$ in the $\mathrm{H}$-Mt model than in the $\mathrm{N}$-Mt model in the lower atmosphere. The difference is small at the middle and low latitudes. It becomes small with increasing height too. As will be mentioned later, planetary waves are weak in the H-Mt model. This is one of the causes of the small difference of temperature between the two models.

\subsection{Wind}

The zonal mean winds are shown in Fig. 11. The result of the $\mathrm{N}-\mathrm{Mt}$ model resembles on the whole that of the ZS model. A strong westerly jet appears at $20^{\circ}$ latitude and its magnitude reaches about $60 \mathrm{~m} / \mathrm{s}$. Another maximum is located at $60^{\circ}$ latitude and its magnitude is about $20 \mathrm{~m} / \mathrm{s}$ at the top of the model. As mentioned before, the strong westerly jet in the low latitudes is generated by the large horizontal gradient of the diabatic heating function $Q$. However, baro- 
clinic waves do not develop well corresponding to the westerly jet in the lower latitudes. It is difficult to explain why the jet is not associated with the cyclogenesis despite its strong baroclinicity.

A large difference from the ZS model is found in the easterly flow near the pole. In the ZS model it appears in the lowest layer and extends southward as far as $50^{\circ}$ latitude. This easterly wind corresponds to the southward meridional flow of the large direct cell in the polar region. In the $\mathrm{N}$-Mt model the easterly flow is limited to a small region near the pole and its top reaches middle troposphere. This feature is consistent with a small direct cell in the polar region and a large indirect cell in the mid-latitudes as will be shown in Fig. 13. The easterly wind near the equator agrees well with that of the ZS model. It is natural because baroclinic waves are very weak in the equatorial region.

The difference of the zonal mean winds between the $\mathrm{N}$-Mt model and the $\mathrm{H}$-Mt model is small as well as in the case of temperature. The intensity and location of the westerly jet agree

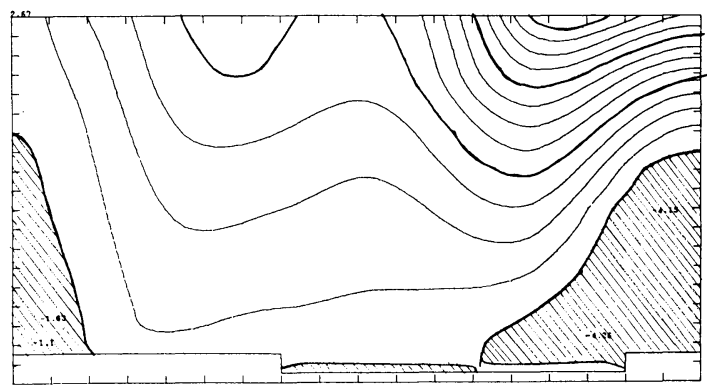

ZONAL WIND (M/SEC)

$S T=0.00$

LAT-H ZONAL MEAN

1 YR 51 DAY 15HR SAMIN O SEC

$B D=5.00$

(a)

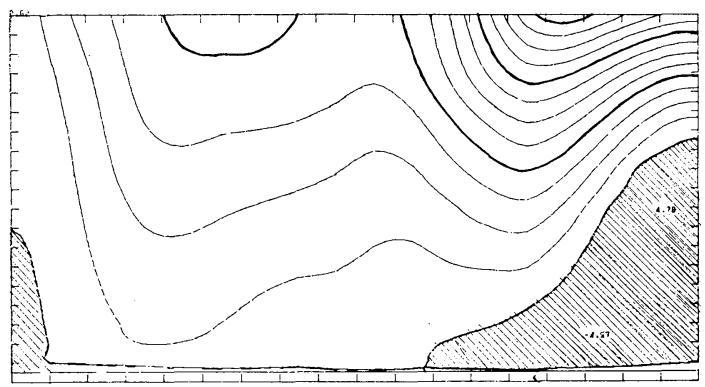

ZJNAL WIND (M/SEC)

$S T=0.00$

LAT-H ZONAL MEAN

1 YR 51 DAY 15HR 54MIN O SEC

$B D=5.00$

(b)

Fig. 11 As same as Fig. 4 except for the zonal means of the zonal winds in the (a) N-Mt model and (b) H-Mt model.

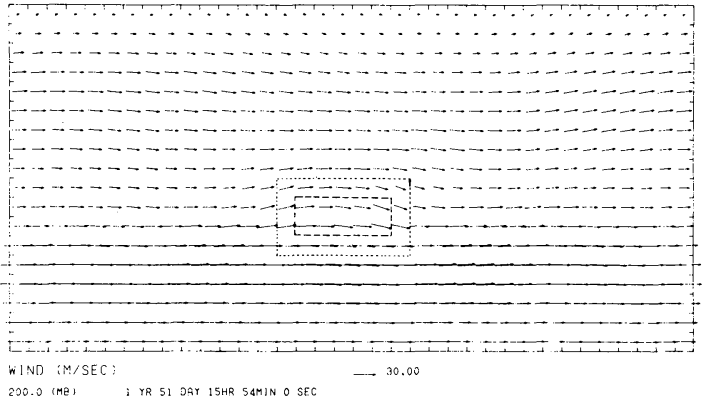

(a)

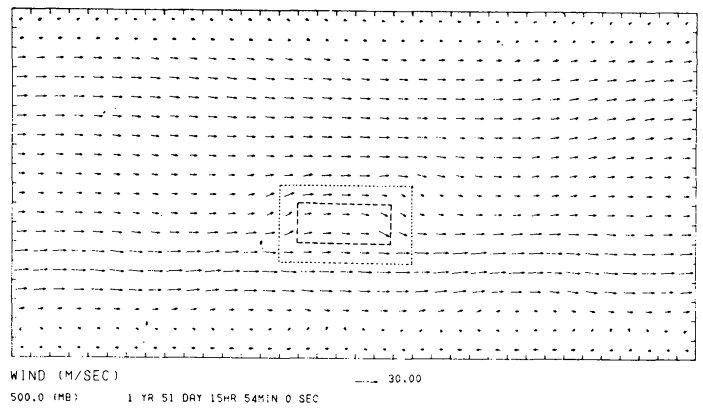

(b)

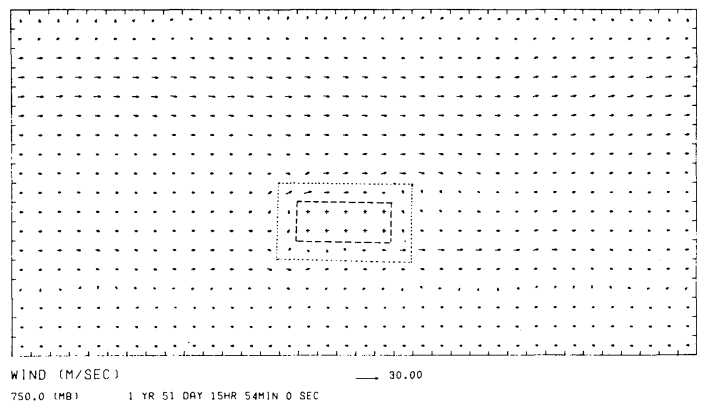

(c)

Fig. 12 Flow patterns in the $\mathrm{H}$-Mt model at the levels of (a) $200 \mathrm{mb}$, (b) $500 \mathrm{mb}$ and (c) $750 \mathrm{mb}$.

very well. This fact, together with small difference of the zonal kinetic energy, indicates that the effects of the mountain on the westerly wind are very weak. Unfortunately, the mountain is placed at $35^{\circ}$ latitude where the westerly wind becomes minimum. The wind velocity is only $6 \mathrm{~m} / \mathrm{s}$ at the height of the top of the mountain. Fig. 12 shows the flow pattern of the H-Mt model. In the lower atmosphere the flow is blocked and goes around the northern boundary of the mountain. However, its intensity is very weak. Over the mountain the flow turns northward at the upstream boundary and goes southward at the 
leeside of the mountain. We see that the anticyclonic circulation is formed over the mountain in this model, though it is weak. However, the perturbation of the wind by the mountain is limited to the neighbourhood of the mountain and stationary disturbances are not observed in the far downstream of the mountain. The flow pattern is nearly zonal except near the mountain.

\subsection{Mean meridional circulation}

Fig. 13 shows the zonal mean of the meridional wind and the vertical p-velocity of the N-Mt model. The indirect cell in the mid-latitudes becomes strong compared with that of the ZS model. It extends from $35^{\circ}$ to $80^{\circ}$ latitude, which agrees well with the observation. It is obvious that the circulation is induced by the effect of baroclinic waves. Corresponding to the expansion of the indirect cell, the direct cell in the polar region becomes narrower, though its intensity does not differ greatly. The change of the Hadley cell in the low latitudes is small. This is consistent to the weak activity of baroclinic waves there.

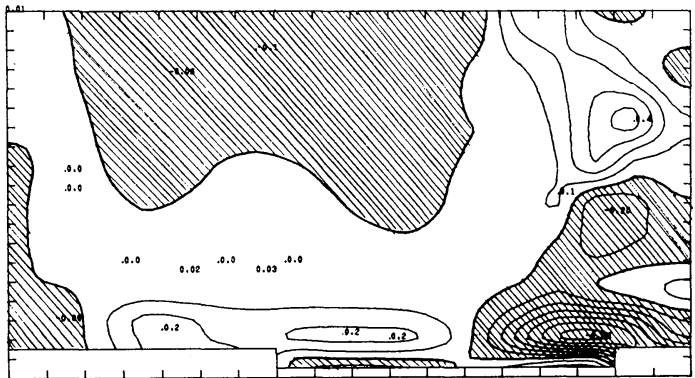

MERIDIONAL WIND (M/SEC)

$S T=0.00$ LAT-H ZONAL MEAN 1 YR 51 DAY 15HR 54MIN O SEC BD $=0.10$

(a)

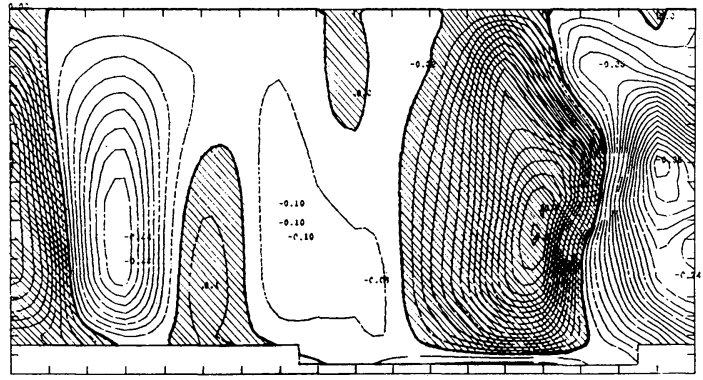

VERTICAL P--VELOCIIY (1.E-4MB/SEC)

$S T=0.00$ LAT-H ZONAL MEAN 1 YR 51 DAY 15HR 54MIN O SEC BD $=0.05$

(b)

Fig. 13 As same as Fig. 5 except for the case of the N-Mt model. Contour intervals are (a) $10 \mathrm{~cm} / \mathrm{s}$ and (b) $5 \times 10^{-6} \mathrm{mb} / \mathrm{s}$.

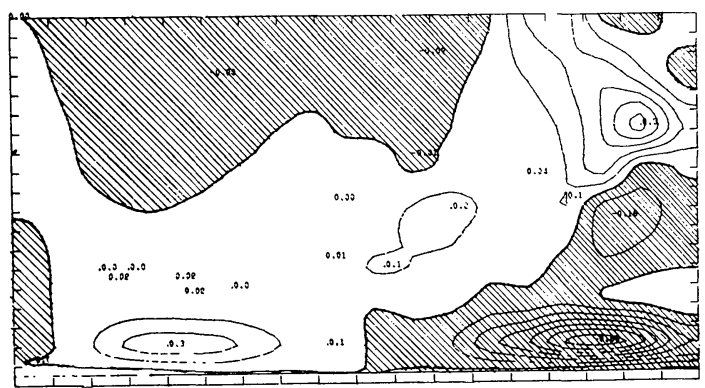

MERIDIONAL WIND (M/SEC) ST $=0.00$ LAT-H ZONAL MEAN 1 YR 51 DAY $15 \mathrm{HR}$ 5 $4 \mathrm{MIN}$ O SEC BD $=0.10$

(a)

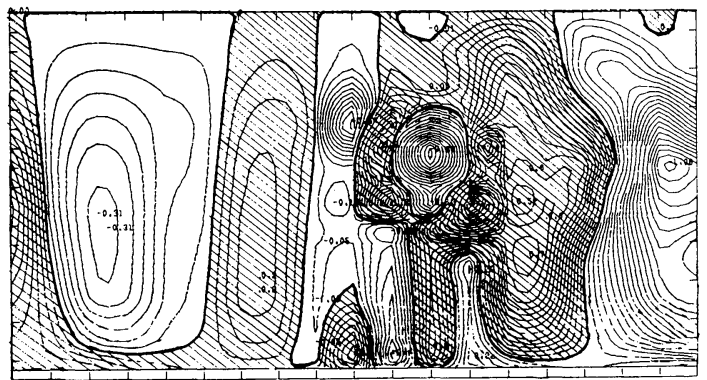

VERTICAL P-VELOCITY (1.E-4MB/SEC) ST=0.00 LAT-H ZONAL MEAN I YR 51 DAY 15 HR $54 M I N$ O SEC BD $=0.05$

(b)

Fig. 14 As same as Fig. 13 except for the case of the H-Mt model.

Fig. 14 shows the mean meridional circulation of the H-Mt model. The Hadley cell extends northward. That is, the axis of the downward motion is located at about $30^{\circ}$ latitude just at the southern boundary of the mountain and the cquatorward flow in the lower layer is observed as far as $40^{\circ}$ latitude, which is by about $10^{\circ}$ north to that of the N-Mt model. The circulation in the mid-latitudes is fairly complicated compared with that of the N-Mt model, as shown in the vertical $p$-velocity field. A large upward velocity near $35^{\circ}$ latitude is the effect of the mountains. Ignoring it there are three cells in the mid-latitudes. It seems difficult to explain this feature by a simple analysis.

\subsection{Surface pressure and geopotential height}

The zonal mean of the surface pressure is shown in Fig. 15. The pressure is the highest in the polar region in the ZS model but it becomes the lowest there in the $\mathrm{N}$-Mt model, i.e., when baroclinic waves are incorporated in the model. This agrees well with the observation and the theoretical consideration. A remarkable dif- 
ference between the $\mathrm{N}-\mathrm{Mt}$ model and the $\mathrm{H}-\mathrm{Mt}$ model is the location and the width of the subtropical high. In the N-Mt model the subtropical high is located at about $30^{\circ}$ latitude and is rela-

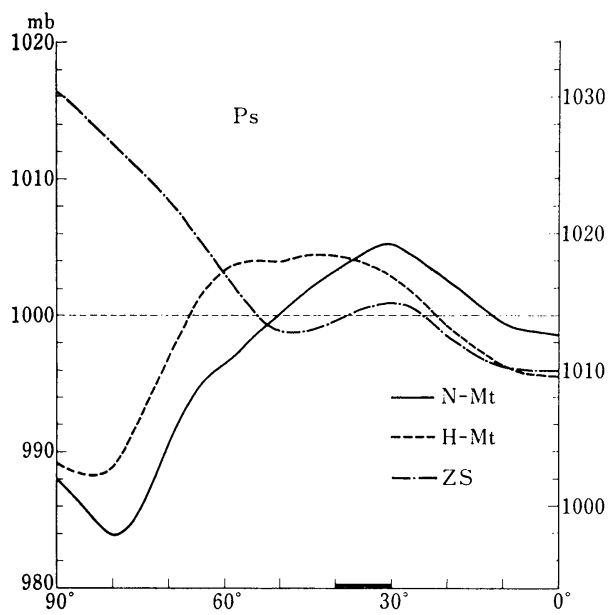

Fig. 15 Zonal mean of the surface pressure in the ZS model (chained line), the N-Mt model (solid line) and the H-Mt model (dashed line). At lefthand side, vertical scale is for the ZS model and the N-Mt model and at righthand side, vertical scale for the $\mathrm{H}-\mathrm{Mt}$ model. Change of the surface pressure due to incorporating the mountain is corrected.

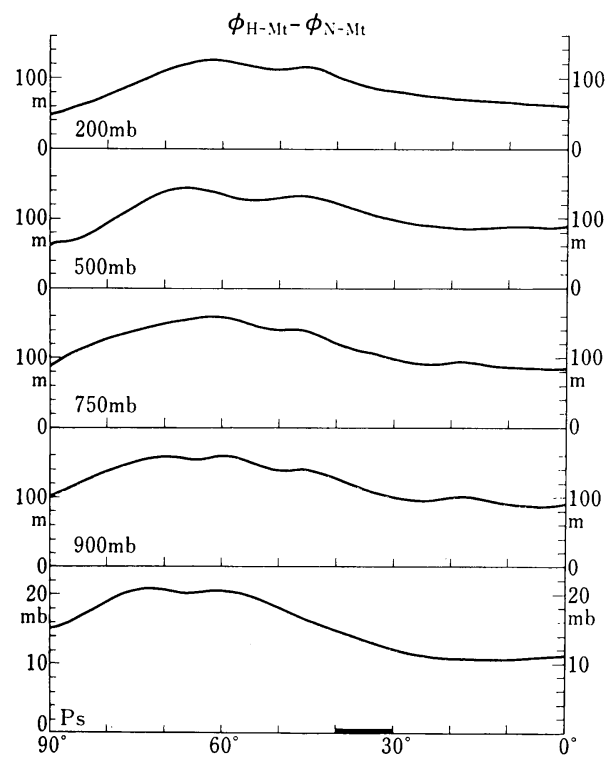

Fig. 16 Differences of the zonal mean geopotential height at $200,500,750$ and $900 \mathrm{mb}$ and the surface pressure in the $\mathrm{H}$-Mt model from those in the $\mathrm{N}-\mathrm{Mt}$ model. tively narrow, while in the $\mathrm{H}$-Mt model it is located at about $45^{\circ}$ latitude and has a broad peak with the $25^{\circ}$ width. The northward extension of the Hadley cell in the H-Mt model as mentioned before is consistent with this shift. Corresponding to the shift, the pressure increases by about $5 \mathrm{mb}$ in the high and middle latitudes and decreases by about $3 \mathrm{mb}$ in the low latitudes. The geopotential height in the upper atmosphere shows similar tendency (Fig. 16). The difference of the geopotential height between the N-Mt model and the H-Mt model is relatively large from $55^{\circ}$ to $75^{\circ}$ latitudes and small in the low latitudes at all heights.

As shown in Fig. 10 the temperature in the lower atmosphere near the pole is lower by about $2{ }^{\circ} \mathrm{K}$ in the $\mathrm{H}$-Mt model than in the $\mathrm{N}$-Mt model. The pressure increase by about $4 \mathrm{mb}$ near the pole is probably due to this cooling. However, since in the latitudes south to $70^{\circ}$ latitude the temperature difference between the two models is small, it is difficult to explain the increase of the pressure near $60^{\circ}$ latitude by the thermal effect. Another possibility for the shift is the dynamical effect of the mountain. By the blocking effect of the mountain, though weak as mentioned before, the westerly jet becomes weak at the latitudes where the mountain is located. This means relative acceleration of the easterly wind. It induces northward meridional flow over the mountain. Therefore, the air mass is transported northward and accumulates north to the mountain. By the increase of the pressure there, the geostrophic adjustment between the weakened westerly wind and the meridional pressure gradient force is achieved. This explanation may be justified by the experiments in Part II, where the blocking effect of the mountain on a barotropic

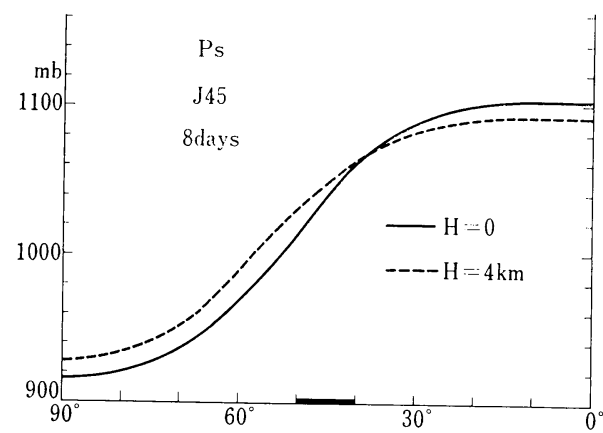

Fig. 17 Zonal mean of the surface pressure at day 8 without the mountain (solid line) and with the mountain (dashed line) in the case of $\mathbf{J} 45$ in Part II. 
westerly basic flow was studied. Fig. 17 shows the surface pressure in the runs with the mountain and without the mountain in one of the experiments in Part II. This shows clearly the increase of the surface pressure in the high latitudes and the decrease in the low latitudes when the mountain is included. We should point out that the shift of the subtropical high in the H-Mt model occurs not only near the mountain but also at all longitudes as shown in Fig. 18. This means that the blocking of the wind is not limited near the mountain.

Since the shift of the air mass is observed at all heights, the phenomenon has barotropic nature. This nature agrees well with the flow over the mountain where the anticyclonic circulation is formed (see Fig. 12). The experiments of Part II showed that the effect of mountains has barotropic nature strongly. The Taylor column effect was observed over the mountain. However, since the jet used there was forced to be restored to a prescribed barotropic wind, it was not concluded that the barotropic nature of the effect of mountains is also important in the case of the baroclinic atmosphere. The northward shift of the subtropical high in the H-Mt model indicates that the blocking effect of the mountain has in some situation barotropic nature even in the baroclinic atmosphere.

The phenomenon mentioned above may be one of the causes of the northward shift of the dry area in the Eurasian continent. The deserts are located to the north of the Tibetan Plateau. However, we should also consider the thermal effects of the mountains and the water vapor for the formation of the dry area. It may also explain the formation of the Siberian high in winter. Manabe and Terpstra showed in their numerical experiment that the Siberian high located at $30^{\circ} \mathrm{N}$ in the model without mountains shifts to $45^{\circ} \mathrm{N}$ in the model with the Tibetan Plateau. This position is in good agreement with the observation. As the one of the causes of the formation of the Siberian high, it is said that the air north to the Tibetan Plateau is strongly cooled on the earth's surface and southward flow of the cooled air is blocked by the Plateau and hence the air mass accumulates there. However, since the axis of the Siberian high extends upward into the upper troposphere without tilting and the maximum of the low temperature at the surface occurs near Verkhoyansk, northeast of the center of the Siberian high, it seems to be difficult to explain the formation of the high only by the cooling

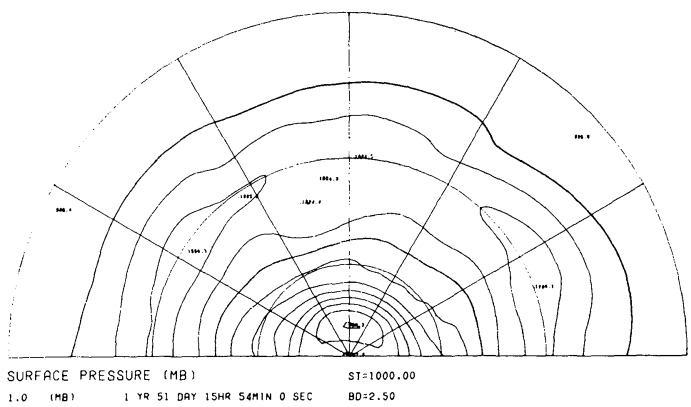

(a)

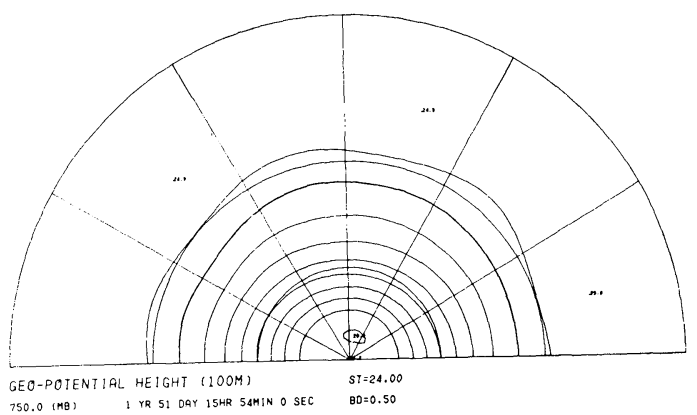

(b)

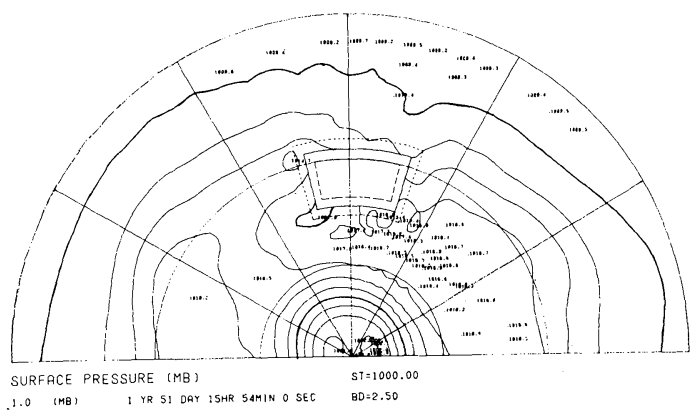

(c)

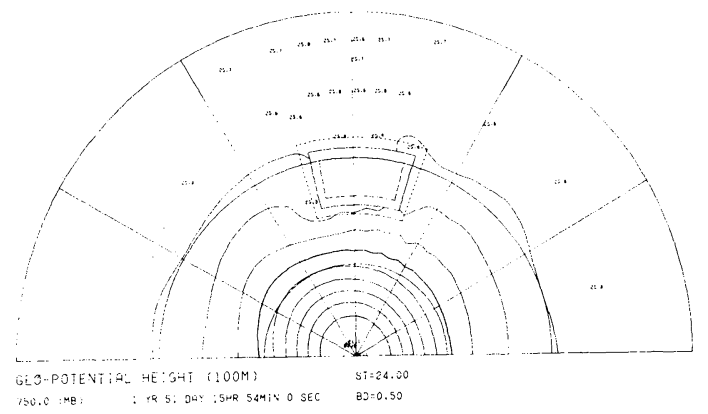

(d)

Fig. 18 Patterns of the surface pressure and geopotential height at $750 \mathrm{mb}$ for the time mean state. (a) surface pressure and (b) geopotential height in the N-Mt model and (c) surface pressure and (d) geopotential height in the H-Mt model. 
effect near the earth's surface. The northward shift of the mass induced by the blocking effect of the Plateau on the westerly flow may also contribute to the formation of the Siberian high to some extent. Since the assumption used in the model and the mountain are very simple, it is necessary to examine the above inferences in a more realistic numerical experiment.

Finally it need some comments about stationary disturbances. As mentioned before, planetary waves are not well produced by the mountain in this experiment. In Fig. 18 it is seen that a weak trough is located in the lee of the mountain in the H-Mt model. However, its magnitude is about $3 \mathrm{mb}$ in the surface pressure. This value is very small compared to that of the planetaryscale disturbances in the real atmosphere and to the magnitudes of baroclinic waves.

\subsection{Eddy kinetic energy}

The eddy kinetic energy is defined by $K E=$ $1 / 2\left(u^{\prime 2}+v^{\prime 2}\right)$ where ( )' denotes the deviation

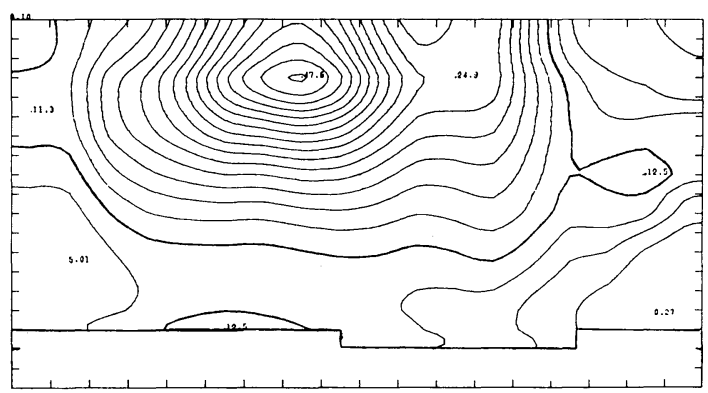

EDDY KINETIC ENERGY ( $(M / S) * * 2)$ $S T=10.00$ LAT-H ZONAL MEAN YR 51 DAY 15HR 54MIN O SEC $B D=2.50$

(a)

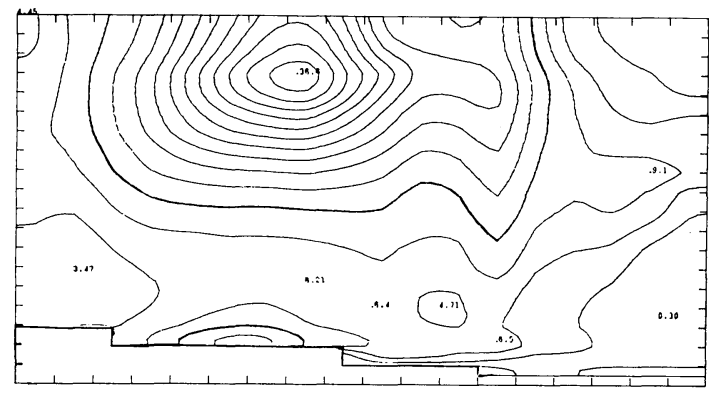

EDDY KINETIC ENERGY ( (M/S)**2)

$S T=10.00$ LAT-H ZONAL MEAN 1 YR 51 DAY 15 HR 54 MIN O SEC BD $=2.50$

(b)

Fig. 19 As same as Fig. 9 except for the zonal mean of the eddy kinetic energy in the (a) N-Mt model and (b) $\mathrm{H}-\mathrm{Mt}$ model. Contour interval is $2.5 \mathrm{~m}^{2} / \mathrm{s}^{2}$. from the zonal mean. Latitude-height distribution of the time mean of the eddy kinetic energy is shown in Fig. 19. The magnitude is considerably smaller than the observation (Oort and Rasmussen, 1971). The maximum of the eddy kinetic energy is located at $200 \mathrm{mb}$ and at $55^{\circ}$ latitude. It coincides with the northern maximum of the westerly jet. The eddy kinetic energy is smaller by about $25 \%$ in the H-Mt model than in the N-Mt model. Since planetary waves are very weak in the $\mathrm{H}$-Mt model (kinetic energy of stationary disturbances is about $1 \mathrm{~m}^{2} / \mathrm{s}^{2}$ ), this means that the activity of baroclinic waves is weaker in the $\mathrm{H}-\mathrm{Mt}$ model than in the $\mathrm{N}-\mathrm{Mt}$ model. Since the mountain is located far south from the latitudes of the maximum activity of baroclinic waves, it is difficult to consider that the mountain has a direct influence on the disturbances. The weak activity of the waves is probably due to the indirect effect of the northward shift of the subtropical high by the blocking effect of the mountain.

\section{Conclusion}

A half-hemispheric general circulation model for the baroclinic atmosphere was integrated for about 150 days. The net heating rate compiled from the observational data are applied to the model as a function of latitude and height as well as the Newtonian cooling which restores the temperature distribution of the model atmosphere to the observational state. The convective adjustment, the nonlinear viscosity and the vertical momentum diffusion are also included. Runs with an idealized mountain (H-Mt model) and without it (N-Mt model) were performed in parallel and the two results are compared. The solution of zonally symmetric model (ZS model) is also investigated.

Various interesting results are obtained from these runs as following:

1) In the N-Mt model the temperature at the pole is lower by about $5^{\circ} \mathrm{K}$ than that of the real atmosphere. The model simulates rather a cold winter, although the heating is the annual mean. This discrepancy is due to the simplicity of the model, i.e., lack of land and sea contrast and other effects. The heat transport by planetary waves is not included in the N-Mt model.

The temperature distribution of the $\mathrm{H}-\mathrm{Mt}$ model differs very little from that of the N-Mt model. The temperature at the pole is lower by about $2{ }^{\circ} \mathrm{K}$ in the $\mathrm{H}$-Mt model than in the $\mathrm{N}-\mathrm{Mt}$ model. It is expected that planetary waves are 
generated in the $\mathrm{H}$-Mt model. However, in our case the waves are very weak and hence the two results turn out to be similar with each other.

2) The patterns of the zonal mean wind in the N-Mt model is fairly similar to that in the real atmosphere, though there are some unrealistic feature. In the low latitudes an extraordinarily strong westerly jet appears. It is driven by the large latitudinal gradient of the diabatic heating near $20^{\circ}$ latitude. There appears second maximum of the zonal wind at $60^{\circ}$ latitude. The easterly wind in the equatorial region is well simulated.

3) In our experiment the mountain is located at the latitudes where the westerly wind is minimum in the H-Mt model and hence the effect of the mountain is weak on the whole. The patterns of the zonal mean wind in the $\mathrm{H}-\mathrm{Mt}$ model is very similar to that of the N-Mt model.

4) The mountain does not excite stationary planetary waves so much as expected from the observation and other studies. This result may be due to the weak westerly wind over the mountain. Resonance wavelength corresponding to the weak wind is smaller than planetary-scale.

5) By blocking action of the mountain and through the Ekman transport (in generalized sense) the air mass accumulates north to the mountain in the H-Mt model. This results in the northward shift of the subtropical high. In the $\mathrm{N}$-Mt model the high belt is located at $30^{\circ}$ latitude and in the $\mathrm{H}-\mathrm{Mt}$ model it is located at $45^{\circ}$ latitude. Corresponding to this shift, the region of downward motion expands northward by $10^{\circ}$ extending to the north of the mountain. This phenomenon may be one of possible causes of the northward shift of the dry area in the Eurasian continent, though we should also consider the thermal effects of mountains and water vapor. We may speculate that this process contributes to the formation of the Siberian high to some degree.

6) Although the model atmosphere is baroclinic, the blocking effect due to the mountain has a barotropic nature. Namely, the Taylor column phenomenon is observed near the mountain. The shift of the subtropical high occurs at all heights. This may be due to the fact that the mountain is very large as discussed in previous Parts I and II.

7) Baroclinic waves are active near the northern maximum of the westerly wind and are weak in the low latitudes. Their intensity is somewhat weak compared to that in the real atmos- phere. There are many possible causes. For example, development of baroclinic waves is generally insufficient in dry models. Low grid resolution may be another cause for it (Simmons and Hoskins, 1975). The activity of the waves is weaker in the $\mathrm{H}-\mathrm{Mt}$ model than in the $\mathrm{N}-\mathrm{Mt}$ model. It does not become clear from this experiment how the mountain influences directly on the behaviour of baroclinic waves because the mountain is located to the south of the active baroclinic zone.

8) The solution of the ZS model is considerably different in the pattern of the temperature and the surface pressure from the observation. The temperature is lower by about $20^{\circ} \mathrm{K}$ in the polar region and is higher by about $5^{\circ} \mathrm{K}$ near the equator in the ZS model than in the real atmosphere. Corresponding to this temperature distribution the surface pressure becomes the highest in the polar region in the ZS model.

9) Compared with the result of Hunt, the present result of the ZS model is somewhat similar to the real atmosphere, though there is a large difference between the ZS model and the real atmosphere. The easterly wind in the equatorial region is simulated. Three cell circulation appears, though its mechanism is different form the real one. They are not simulated in Hunt's model. It is supposed that one of the causes of the difference comes from the different treatment of the nonlinear viscosity in the horizontal diffusion term. The nonlinear viscosity of Smagorinsky's type used in the Hunt's model diffuses the westerly momentum produced in the mid-latitudes much efficiently to the low latitudes and hence the westerly wind may dominate at the equator.

10) Comparison of the ZS model with the $\mathrm{N}-\mathrm{Mt}$ model shows the important role of baroclinic waves on the poleward heat transport. In the N-Mt model the temperature at the pole increases markedly by $15^{\circ} \mathrm{K}$ and the surface pressure becomes lowest there. The indirect cell becomes very strong and expands as is well known from theory and observation. However, the pattern of the zonal mean wind is only slightly different between the ZS model and the N-Mt model. The effect of baroclinicity on the zonal flow seems to be small in this experiment.

11) Finally, it is remarked that the distribution of the heating function which we used might not be relevant to the investigation of the present problems in the sense that a strong westerly jet is produced at too low latitudes. The results may be somewhat different if we adopt a different 
heating function. The mountain is very simplified compared with the real ones. In order to apply the results obtained by our numerical experiment with simplified assumption to the quantitative explanation of the phenomenon in the real atmosphere, it may be necessary to perform a numerical experiment with more realistic situations.

\section{Acknowledgements}

This paper (Parts I, II and III) is the main part of my doctor dissertation (1977).

I would like to express my sincere gratitude to Prof. K. Gambo for his guidance and encouragement. I am also much appreciating Prof. T. Matsuno whose helpful suggestions and comments were invaluable in the formation and completion of this study. I must express my further thanks to both of them for giving me valuable advice and criticisms on the original manuscript.

I wish to extend my hearty appreciation to nice persons without whose help this study could not have been completed. Dr. A. Kasahara of NCAR brought me Phillip's paper on which examinations of schemes are constructed and spent his valuable time to discuss various things during his visit at Tokyo University. Drs. Y. Kikuchi, H. Kondo and Y. Masuda of Electronic Computer Center of Japan Meteorological Agency pointed out the outstanding problems in the numerical forecasting model. Dr. H. Kida of Meteorological Research Institute gave me useful suggestions about the numerical experiments.

Thanks are also extended to Mr. Y. Fujiki for drawing the figures and Mrs. K. Kudo for her expert typing of the manuscript and assistance of computer operation.

The computations were performed by HITAC $8800 / 8700$ at Tokyo University Computer Center.

\section{References}

Edelmann, W., 1974: Über der Einfluss von Gebirgen and barokline Vorhersagen. Annalen der Meteorologie, Nr. 9, 107-114.
Egger, J., 1972: Incorporation of steep mountains into numerical forecasting models. Tellus, 24, 324-334.

Gilchrist, A., G. A. Corby and R. L. Newson, 1973: A numerical experiment using a general circulation model of the atmosphere. Quart. J. Roy. Meteor. Soc., 99, 2-34.

Hunt, B. G., 1973: Zonally symmetric global general circulation models with and without the hydrologic cycle. Tellus, 25, 337-354.

Kasahara, A., and W. M. Washington, 1971: General circulation experiments with a six-layer NCAR model, including orography, cloudiness and surface temperature calculations. J. Atmos. Sci., 28, 657-701.

Kida, H., 1977: A numerical investigation of the atmospheric general circulation and stratospherictropospheric mass exchange: I. Long-term integration of a simplified general circulation model. J. Meteor. Soc. Japan, 55, 52-69.

Manabe, S., J. Smagorinsky and R. F. Strickler, 1965: Simulated climatology of a general circulation model with a hydrological cycle. Mon. Wea. Rev., 93, 769-798.

, and R. F. Strickler, 1964: Thermal equilibrium of the atmosphere with a convective adjustment. J. Atmos. Sci., 21, 361-385.

-, and T. B. Terpstra, 1974: The effects of mountains on the general circulations of the atmosphere as identified by numerical experiments. J. Atmos. Sci., 31, 3-42.

Mintz, Y., 1968: Very long-term global integration of the primitive equations of atmospheric motion: An experiment in climate simulation. Meteor. Monographs, 8, 20-36.

Newell, R. E., D. G. Vincent, T. G. Dopplick, D. Ferruzza and T.W. Kidson, 1971: The energy balance of the global atmosphere. Proc. London Conference on general circulation, Roy. Meteor. Soc., 42-90.

Oort, A. H., and E. M. Rasmusson, 1971: Atmospheric circulation statistics. NOAA Prof. Paper 5, Govt. Printing Office, Washington, D.C., $323 \mathrm{pp}$.

Simmons, A. J., and B. J. Hoskins, 1975: A comparison of spectral and finite-difference simulations of a growing baroclinic wave. Quart. J. Roy. Meteor. Soc., 101, 551-565. 


\title{
大気大循環に及ぼす山岳の力学効果 \\ III. 傾圧大気の大循環に対する山岳の効果
}

\author{
中 村 \\ 東京大学理学部地球物理学教室
}

観測から求めた簡単化した非断熱項と Newtonian cooling と $6.5^{\circ} \mathrm{K} / \mathrm{km}$ の対流調節を先に開発した数值モデル に入れて, 約 150 日積分し傾圧大気に対するチベット高原型の山の力学効果を調べた。 Nonlinear viscosity, 鉛直 渦粘性の効果も含まれている。

山のないモデルでは, 中緯度の偏西風, 熱帯の偏東風, 3 細胞子午面循環など現実大気と良く似た大循環の特徵が 再現出来た。傾圧不安定波も良く発達した。しかし， $20^{\circ}$ 付近にある非断熱項の強い南北傾度に対応して, 亜熱帯シ ェットが南に片寄り強くなり過ぎた事，傾圧波がやや高緯度に現われる事などの欠点があった。

山を入れた場合, これらの大きな特徵は余り変化しなかった。最も顕著な変化は, 山のないモデルでは $30^{\circ}$ 付近に あった亜熱帯高圧帯が，山の入ったモデルでは $45^{\circ}$ 付近にまで北上した事である。亜熱帯の平均子午面下降流域も北 に拡大した。これは山のブロッキング効果によって減速された偏西風に地衡風バランスするため, 大気が北核動し たためと解釈できる。この現象はニーラシア大陸上で乾燥地帯が北上している事実の理由の一つとして考觉られそう である。またシベリア高気圧の形成にも関係しているかも知れない。山の緯度では西風ジェットが弱かったため, 定 常プラネタリー波は余り励起されなかった。また, 傾圧不安定波の振舞いに対する山の影響もごの実験でははっきり 見られなかった。

更に, 東西方向に擾乱を禁じた解 (Zonally symmetric circulation) を求めた。現実大気とは非常に異なってい る。Hunt (1973) の同様の解とも非常に異なって抢り, その一因として水平の nonlinear viscosity のスキームの 差が考兄れる事がわかった。 